\title{
Technological Education, Training and Process Identity
}

\section{Educación tecnológica, capacitación e identidad de procesos}

\author{
Nikolay Nikolaevich Romanov* \\ North-Eastern Federal University, Yakutsk, Rusia \\ ORCID: https://orcid.org/0000-0002-3413-7123 \\ Aleksandra Ivanovna Zakharova \\ North-Eastern Federal University, Yakutsk, Rusia \\ ORCID: https://orcid.org/0000-0003-0360-1701 \\ Alexandra Fyodorovna Bortnik \\ North-Eastern Federal University, Yakutsk, Rusia \\ ORCID: http://orcid.org/0000-0002-6754-2301 \\ Mariya Nikiforovna Romanova \\ North-Eastern Federal University, Yakutsk, Rusia \\ ORCID: http://orcid.org/0000-0002-3906-3944 \\ Marianna Alekseevna Manasytova \\ North-Eastern Federal University, Yakutsk, Rusia \\ ORCID: http://orcid.org/0000-0002-0814-3503
}

Recibido 07-12-19 Revisado 15-01-20 Aprobado 10-03-20 En línea 16-03-20

*Correspondencia

Email: NikolaiNRomanov@yandex.ru
Citar como:

Romanov, N.N., Zakharova, A.I., Bortnik, A.F., Romanova, M.N., Manasytova, M.A. (2020). Technological Education Training and Process Identity. Propósitos y Representaciones, 8(3). doi: http://dx.doi.org/10.20511/pyr2020.v8n3.485

\footnotetext{
(C) Universidad San Ignacio de Loyola, Vicerrectorado de Investigación, 2020.

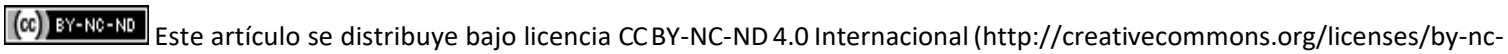
$\mathrm{nd} / 4.0 /)$.
} 


\section{Summary}

The paper presents the results of the analysis of technological education, namely the identification of educational technology and the technological process. It was found that most major technology creators transform both their ideas and their techniques into modern technological operations as well as educational technologies. The authors propose that the training process may be regarded as technological in nature and the one that embraces the same methods of analysis (including activity approaches). In other words, the analysis of the educational process is identical to the analysis of technological process. In methodological terms, the closest to that step sequence is project-based learning. The conclusion is reached by drawing on the analysis of training processes in general and on the analysis of operational training in particular including the step-by-step performance of certain technological operations.

Keywords: Analysis; System; Activity; Technology; Training; Contradictions; Transformation.

\section{Resumen}

El documento presenta los resultados del análisis de la educación tecnológica, es decir, la identificación de la tecnología educativa y el proceso tecnológico. Se descubrió que la mayoría de los principales creadores de tecnología transforman tanto sus ideas como sus técnicas en operaciones tecnológicas modernas, así como tecnologías educativas. Los autores proponen que el proceso de capacitación se considere de naturaleza tecnológica y que abarque los mismos métodos de análisis (incluidos los enfoques de actividad). En otras palabras, el análisis del proceso educativo es idéntico al análisis del proceso tecnológico. En términos metodológicos, lo más cercano a esa secuencia de pasos es el aprendizaje basado en proyectos. Se llega a la conclusión recurriendo al análisis de los procesos de capacitación en general y al análisis de la capacitación operativa en particular, incluido el desempeño paso a paso de ciertas operaciones tecnológicas.

Palabras clave: Análisis; Sistema; Actividad; Tecnología; Formación; Contradicciones; Transformación.

\section{Introduction}

Each new technology emerges in the presence of technologies that are already known due to their improvisation and trial-and-error testing. This idea underlies the study as a hypothesis.

In The New and the Old, the 1966-67 cycle of linocut printings by Valeryan Vasilyev (1938-1970), one printing named "Sardaana" depicts a master holding a flower with choron, a Yakut pot for mare's milk, in the background. I. Potapov described this printing as follows: "The undoubted pinnacle of the whole series is 'Sardaana' that conveys so much of the master choron maker's spiritual completeness. It is he who found his way into the beauty of his native nature and used his fantasy to transfer its regularities into the shapes of his creations. Cups' and pots' outlines, the ornament, bends of trees and flame-like autumn leaves expressed in the language of graphical metaphors are filled with genuine poetic meaning generating the wave of associations. And the flower of sardaan is present there as an embodiment of beauty and artistic perfection."

According to L.S. Vygotsky, in the process of interiorization (in Latin interior means "from the outside to the inside") there is a transformation of something external (a mark, a 
spoken word) into something internal in the person's mind (an image, an element of internal speech). He identifies three stages of interiorization in ontogenesis and phylogenesis:

1) Teacher-child (the verbal action of the teacher, inducing the child to do something).

2) Child-teacher (the child starts to exercise verbal influence, by adopting adults' way of communication).

3) Child (the child starts to exercise verbal influence on himself) (Vygotsky, 1996).

The process of forming higher psychological activity in ontogenesis spans decades. Beginning in speech communication, it ends in full symbolic activity, whereby man is involved in mastering cultural values. Meanings that motivate the person cognitively and emotionally become the key components of his/her inner world.

Thus, L.S. Vygotsky used the concept of interiorization to solve the problem of transition from the non-psychic to the psychic realm. According to Vygotsky, the higher psychic functions at first are formed as external forms of activity and only then interiorization transforms them into individual psychic processes.

The purpose of our research is to analyze the technological process according in the context of technology learning. For this purpose, the tasks on substantiation of ethnopedagogical ideas in the field of labor training have been singled out. It is considered generally accepted and undisputed that classes of technology education awaken students' interest in work, their taste for the beauty of the world of objects, as well as create a favorable ground for solving problems of professional orientation and help them to master the general scientific principles of production organization and basic skills and abilities.

\section{Literature review}

The problems of and prospects for the development of technological education and training amid changing social, economic and technological conditions affect the increasing educational aspirations of future generations and point to the need for a critical discussion on the management of professional training, the insufficient permeability between professional and academic education and structural knowledge-oriented changes occurring in society (Seeber and Seifried, 2019).

Ethniocultural and social keynotes of pedagogic training in a country like Russia with its diversity of languages, traditions, nationalities and cultures, the pedagogical traditions of peoples are of great importance. The idea of giving everyone an obligatory amount of human knowledge, which is the basis of self-identification (Morova et al., 2015), plays an important role.

Art education as a way of preserving traditional ethnocultural identity (Kolesnik et al., 2018) is an important condition for the development of technological education. Young people in the education field explore the many interconnected social contexts that they have to live and orient themselves in (Kolesnik et al., 2018).

The structure of 21 st century competences of students in education is diverse. The continuous development of information and communication technologies (ICT) in today's knowledge-oriented society has led to the demand for new competences, called 21 st century competences. They include higher level competences (highly qualified thinking and teamwork skills) and ICT competences (technological, pedagogical and ethical) (Almerich et al., 2020). 
Integration of learning content and development of students' independence and creativity also play important roles in training future teachers of technology (Romanova et al., 2018).

The theory and practice of culturally sensitive education is discussed in Aronson and Laughter (2016). Bolin and Blandy (2003), meanwhile, identified seven points about the need to study material culture in art education.

The problems of developing the sphere of labor training and education were considered by many authors (P.R. Atutov (1997), V.M. Kazakevich (1999), N.M. Konysheva (1999), G.I. Kruglikov (2002), A.V. Leontiev (2000), et al.).

Our region embraces a mixture of unique cultures and traditions of the Yakuts, Evenks, Yukaghirs, Dolgans and Chukchs, promoting their dynamic development. The region has developed and is implementing comprehensive programs aimed at supporting the cultural diversity of the ethnic identities of small indigenous peoples, as well as the preservation of traditional crafts of the Far North (Bortnik et al., 2019).

In the globalizing world the development of multicultural and ethnocultural competencies of students is a means of preparing them for global (not international) successful cooperation in various economic spheres in a growing world market and a means of preventing intercultural conflicts (Almazova et al., 2019).

The process of developing students' ethno-cultural competence in the context of globalization is carried out effectively provided that various subjects and disciplines use the material related to regional and ethnic cultural peculiarities, as well as an integrated approach to the development is implemented an educational process that takes into account the ethnic identity and ideology of a multicultural paradigm in addressing pedagogical, educational and ideological tasks (Karpushina et al., 2019).

C. Hällgren presents the Art Blended Research approach based on an understanding of what is more than one can see at first sight. In conclusion, the strength of this approach is not in the ability to explain "what it is that". It explores and inspires "what is to be" instead.

An analysis of relevant literature and pedagogical practice shows that, regardless of the increased attention to the study of problems of labor training and education, a number of its aspects remain insufficiently studied. First of all, this refers to the need to identify the following productive contradictions:

- Aesthetic (artistic) and functional (utilitarian) aspects in making a product of any material, form, style;

- The image (abstract and speculative) and the specific design of the product;

- Professional artistic attitude with its generally accepted canons and amateur attitude; work of art and handicraft product; artistic creation in fine arts and folk art (folk art, applied art or art, folk applied art, decorative-applied art or art).

In the course of establishing the identity of the technological process analysis, we took into account the results of previous studies (Bortnik et al., 2019; Romanova et al., 2018; Zakharova et al., 2017). 


\section{Method}

In the course of the research, empirical methods (survey, questionnaires) were used, and an applied workshop was introduced to highlight original ideas in order to emphasize the practical significance of the article. While studying pedagogical and in-process (technological) situations, we used different types of analysis (comparative, reflexive, etc.) and took into account certain standpoints (Robert Anton Wilson (1998); G. Frankfort (2001), C. Frit (2007), S. Hawking (2012), Lester Embry (2005), et al.).

The analysis was carried out in the following order:

1) Collection of factual material as parts of the future system, - initial stage;

2) Linking the parts to each other by the most obvious external features, - the stage of highlighting the external links;

3) Determination of the wording of the newly emerging interconnection of parts, - the stage of formulation;

4) Gathering of connections of parts, - the stage of identification of internal connections;

5) Determination of adequacy of different connections of the parts by their main parameters (characteristics, properties), - the stage of modeling;

6) Marking of the general principle (action, functioning), - the final stage.

\section{Results}

Yakut masters have a huge advantage being the part of the nation that tends to ponder over the problems of creative work in the inner speech. Yakut has an entire inner Language that cannot be translated into any other language. Famous folk masters were lucky to believe someday in their way of understanding and embodying the world in images. Such a language is transmitted archetypically, by inheritance.

The unique experience of A.N. Zvereva, a recognized master of the patchwork mosaic, receives the highest praise in many countries of the world. Apparently, A.N. Zvereva, when choosing her theme, proceeds from the making of a cultural event, genesis of a certain genre of art, study of museum samples.

A.N. Zvereva (2009) created her mosaic sewing technique (carpets, rugs, bedspreads, capes, etc.). She learned how to collect shreds back-to-back when a utilitarian seam is used as a decorative technique by carefully marking the outer pattern, passing through the contour of inserts between different parts of the product. Thus, the product looks more voluminous and visually attractive due to the clear identification and emphasis of constructive and linear decorative features.

According to A.N. Zvereva, it is necessary to maintain the principle of readability of ornament and background, developed in the national design (for example, geometric/spiral and plant motifs). One has to use concentric compositions with different radii and a common center in each individual case by creating certain transformations based on simple geometric shapes (square, rhombus, oval, circle and etc.). 
She interestingly notes that after ten years it is difficult for a girl to become a recognized master in future, if she had not been taught basic knowledge and skills in sewing, and this, in fact, is an ethnic-pedagogical basis.

Technologically, when manufacturing of a panel from shreds:

1) It is possible to vary proportional ratios of various elements of a thing, its texture and color combinations;

2) A different shade is introduced, which is peculiar to the given thing in the nationalstyle feature;

3) The mosaic sewing technique is used;

4) The shreds are assembled back-to-back when the utilitarian seam is used as a decorative technique due to the careful marking of the external pattern of patterns, the passage along the contour of inserts between different parts of the product;

5) The principle of readability of the ornament and the background, developed in the national design (for example, geometric/spiral and plant motifs of the ornament) is maintained;

6) There is an access to concentric compositions with different radii and a common center in each individual case by creating certain transformations based on simple geometric forms (square, rhombus, oval, circle) (Zvereva, 2009).

A well-known fashion designer, People's Master of Decorative and Applied Art of Yakutia A. N. Filippova (2016) believes that:

1) The nature of the birth of future specimens comes from the past, born in the past:

- From the Yakut heroic epos "Olonkho" (the harmony and coherence of the poetic content is expressed in musical words, encouraging imagination to produce fantastic visions);

- Each author goes through a mystical world that takes them far into an unknown world, enriching, already now, his world of free fantasy;

- Each author has his lyre sound differently (pictures of beautiful images in his clothes);

- But, they are not yet fashionable clothes, the images are transformed by a clue of spiritual emotions, experiences.

2) Therefore, we need creative research, we need to get closer to the way (style) of modern life;

3) The clothes framing the human image each time individually, as a theatrical scenery, when a person - an actor in this theater - dresses according to his own inner inclination, and the models are the carriers of the idea;

4) The author does his creative work to enrich people with spiritual energy, rejoicing in beauty. The author creates by fulfilling the mission of the creator and spreading the beauty. Behind them "remains", the future is fixed, becoming even more beautiful thanks to the beauty based on the creations of past generations; 
5) The lyrical ornament "Kouor oyu-oyuor" (Filippova, 2016) is widely used.

As a rule, people lose their skills, secrets of technology with time. The authors and carriers of those cultural texts that were once accepted by the community as a common value die. Recognized masters, as it happens, often are reluctant or do not pass on the secrets of their creative skill to others (including their loved ones). But they leave behind artifacts as silent witnesses of their former suffering, searches, rare finds, ideas, insights. There is even one hypothesis, according to which the secrets of craftsmanship in some incomprehensible way are preserved in the words that we now use without unnecessary etymological reasoning. Indeed, before "suruk-bichik" ("writing") was "oyu-bichik" ("drawing"). Earlier Yakuts used to say "oyuta onor" ("make a drawing"), "oyuta bys" ("cut a drawing"), i.e., the pre-written Yakut culture was based on drawing, patterns, ornaments on some particular material.

But it was the blacksmiths who had a special gift for creativity. Not without reason, their gift was exalted above the gift of speech. As no one else, the future blacksmith was not just trained, but dedicated. Such schools of skill are based on the oral transmission of not only experience, but also the gift of creating the necessary conditions for the student to develop his personality.

Since 2006, in the Tattinsky ulus under the leadership of Master Boris Neustroyev (Mandar Uus) a year-round camp under the name "Mandar кыhата" has operated welcoming children from all over the country. Boris Fyodorovich notes that when he just talks to the children, they sit quietly and listen, but do not always absorb what they hear. However, when they are doing something (sharpening, sawing, knocking with a sledgehammer, hammer, etc.), they deeply penetrate into the essence of what they are doing. Such feasible physical work is on a par with a conversation and creates a situation of learning new things. As he writes: "They come home transformed" (Neustroyev, 2004).

According to B. Neustroyev, children from an early age have to be taught to overcome difficulties. There are so many obstacles and difficulties in life and a child should not be afraid of them. For this purpose, one of the effective ways is a discussion form of training organization. Mandar Uus skillfully uses this method to teach his wards to think, involving them in philosophical conversations during their working life. B. Neustroyev, having the art of Socratic dialogue, is able to ask the interlocutor questions that put him in a situation of constant reflection, proof of the fidelity of his thoughts, rejection of compromised statements and ascent to philosophical reflection. He is convinced that a child who is able to argue has a more sophisticated mind and learns to think and analyze.

According to B. Neustroyev, growing up in dysfunctional families, children have difficulties in coming into contact, as first, their eyes are extinct, the conversation is reluctant, but when they harden iron, working by the sweat of their brow, then changes and their consciousness, in the eyes there is a light. During physical labor, when young men hammer iron, he specifically asks leading questions, leading to reflection, stirring up a controversial thought; and gradually in the eyes of silent young men an interest appears, as they begin to argue, some prove that the thought is correct, others - that it is wrong, it happens that comes to tears, but eventually come to the right conclusion, a single solution. During such disputes, young men forge iron with special zeal.

In the school of "Mandar кыhaтa" such a joint activity of boys with B. Neustroyev is an important factor in their full development, i.e., entering the system of activity with an adult; the child develops as a person in the process of their own activities. Thus B. Neustroyev acts as "уһуйааччы" (the master). Thus, at school, no one teaches young men anything on purpose: the master is engaged in his own business, and young men are included in this activity. 
In the process of such activity, young men first observe the master, then help him and after that act on their own and through this learn the craft, trying, creating, experiencing. This can be called a skill training technology "уһуйуy" or a skill school, which involves joint activities to teach a particular craft.

If a developing environment is organized taking into account the peculiarities of the development of young men, a gender approach to the educational process using the "Uhuyuu" ("School of Excellence") technology is implemented, which ensures the development of a person and the education in an environment of equal social partnership between school, family and society (Neustroyev, 2004).

In addition, the work of B. Neustroyev confirms the hypothesis that the sequence of operations (for example, labor ones) contributes to the formation of skills useful for the development of arbitrariness and the development of speech.

\section{Discussion}

These contradictions made it possible to formulate the research problem, which is the lack of practical experience in formulating the phenomenon of the emergence and formation of new ideas, in particular, in the field of labor training, education in general and training in certain technologies. The problem we have highlighted continues to be the subject of a still small number of studies.

If one is trying to uncover the essence of the contradiction: for example, when, on the one hand, you cannot teach someone else's knowledge, then on the other hand, any student must show his personal attitude to information. Or try to analyze the willingness of a master (author) to transform the darkest side of his personality into something valuable for many. This idea is based on psychoanalytic notion that there is an inverse relationship between satisfying human aspirations and culture, as the greater the suppression, the more cultural achievements. Such is the price for transforming the original gross vital energy into cultural value.

\section{Conclusions}

All the authors mentioned above show how ideas and traditional craft techniques get transformed into modern technological operations and, concurrently, into teaching technology. Thus, the transfer of social experience from one generation to another takes place; the transfer does not occur as a simple handing over of knowledge and skills, but as a transformation.

Our study also justifies the standpoint that the educational process is the particular instance of the technological process, and therefore it is characterized by the same methods of analysis that are accepted for technological processes (including production-oriented ones). In other words, the analysis of the technological process is identical to the analysis of the learning process. The analysis of both the technological process and the class organization includes 4 stages:

1) Introductory (initial, organizing, motivating) stage

2) Current (main) stage

3) Repeated (corrective) stage

4) Final (control) stage. 
The methodology that's most similar to the above sequence of phases is that of the algorithm for organizing and conducting classes based on the project-based learning framework.

For the subject of technology, classes could also be organized based on the Gastev concept of "labor attitudes" (19) that involves the following: 1) collecting the available instructive and technological maps; 2) making a list of the technological operations; 3) accessing the formulation of definitions by grouping operations under a common name; 4) describing labor movements; 5) choosing the most optimal movement; 6) developing exercises; 7) developing a simulator model; 8) formulating guidelines; and 9) presenting the newly developed technological map (project defense).

\section{References}

Alaca, I.V., Aktaş, B.M. (2019). Exploring material culture of carpets in Turkey via an art project. Intellect, 18(1), 17-34.

Almazova, N., Baranova, T., Khalyapina, L. (2019). Development of students' polycultural and ethnocultural competences in the system of language education as a demand of globalizing world. Advances in Intelligent Systems and Computing, 145-156.

Almerich, G., Suárez-Rodríguez, J., Díaz-García, I. (2020). Structure of 21st century competences in students in the sphere of education. influential personal factors. Educacion XX1, 23(1), 45-74.

Aronson, B., Laughter, J. (2016). The Theory and Practice of Culturally Relevant Education: A Synthesis of Research Across Content Areas. Review of Educational Research, 86(1), 163-206.

Atutov, P.R. (1997). Didactics of technological education: Book. for the teacher. Moscow: InCh.

Baisheva, M., Golikov, A., Prokopieva, M., Popova, L., Zakharova, A., Kovtun, T. (2018). The Potential of Folk Tabletop Games in the Development of the Intelligence and Creativity of Children. Espacios, 39(23).

Bolin, P.E., Blandy, D. (2003). Beyond visual culture: Seven statements of support for material culture studies in art education. Studies in Art Education, 44(3), 246-263.

Bortnik, A., Zakharova, A., Romanova, M., Stepanova, L., Romanov, N., Pavlova, E. (2019). Prospects for the development of vocational secondary education in the conditions of the Far North (Republic of Sakha-Yakutia). Aeterna, PP40.

Eisner, E. (2008). Art and knowledge. Handbook of the Arts in Qualitative Research.

Embry, L. (2005). Reflective analysis. Moscow: Three Squares.

Filippova, A.N. (2016). Fantasies of Filippova Augustina. Yakutsk: Bichik.

Frankfort, G., Frankfort, G.A., Wilson, J., Jacobsen, T. (2001). In anticipation of philosophy. Spiritual searches of an ancient person. Moscow: Science.

Frith, C. (2016). Making up the mind: how the brain creates our mental world. Maiden: Blackwell Pub.

Gastev, A.K. (2011). How we should work: Practical introduction to the science of labor organization. Soviet production management. Moscow.

Hawking, S., Mlodinov, L. (2012). The Grand Design. St. Petersburg: Amphora.

Karpushina, L.P.,Yakunchev, M.A.,Gorshenina, S.N. (2018).Advances in Intelligent Systems and Computing. Ethnocultural approach implementation in general music education as a socialization factor of children and adolescents. Astra Salvensis, 6, 561-569.

Kazakevich, V.M. (1999). Conceptual approaches to the selection and construction of training content in the educational field "Technology" for the primary school. Moscow.

Kolesnik, M.A., Libakova, N.M., Sertakova, E.A. (2018). Art education as a way of preserving the traditional ethnocultural identity of indigenous minority peoples from the North, 
Siberia and the Far East. Novosibirsk State Pedagogical University Bulletin, 8(4), 233247.

Konysheva, N.M. (1999). Methods of labor training for primary school students. Basics of design. Moscow: Flint.

Kruglikov, G.I. (2002). Technique for teaching technology with a practical course. Moscow: Academy.

Leontiev, A.V. (2000). Technology of business activity. Psychological journal, 21(1), 25.

Morova, N.S., Kuznetsova, L.V., Lezhnina, L.V.,Talanova, T.V. (2015). Ethnocultural and social dominants of pedagogical education in conditions of national region. Review of European Studies, 7(8), 182-187.

Neustroyev, B.F. (2004). Oyuu tyla. Aiyy tyla. Yakutsk.

Pavlova, M.B., Pitt, J. (1988). "Technology" educational area: Theoretical approaches and guidelines. Nizhny Novgorod.

Romanova, M., Zakharova, A., Bortnik, A., Romanov, N., Zakharova, A. (2018). Method for Self-Analysis of the Level of a Technology Teacher's Research Skills Development. Espacios, 39(23).

Romanova, M.N., Zakharova, A.I., Bortnik, A.F., Romanov, N.N., Zakharova, A.A. (2018). The method for self-analysis of the level of a technology teacher's research skills development. Espacios, 39(23).

Seeber, S., Seifried, J. (2019). Challenges and development perspectives of vocational education under changed framework conditions. Journal for Educational Science, 22(3), 485.

Stevenson, J. (2004). Philosophy. Moscow.

Takhokhov, B.A. (2019). Development of students' ethno-cultural competence in the context of globalization, Aeterna, 9(4), 73-79.

Timmerman, C., Clycq, N., McAndrew, M., Braeckmans, L., Mels, S. (2016). Youth in education: The necessity of valuing ethnocultural diversity. Youth in Education: The Necessity of Valuing Ethnocultural Diversity, 1-265.

Vygotsky, L.S. (1996). Pedagogical Psychology. Moscow: Pedagogy-Press.

Wilson, R.A. (1998). Psychology of evolution. Kiev: Sofia.

Zakharova, A., Bortnik, A., Romanova, M., Romanov, N.N., Nikolaeva, A.D., Kolpakova, A.P. (2017). On unity of systemically important principles for managing the process of development of future bachelors competences. Espacios, 38(55), 27.

Zvereva, A.N. (2009). Olonkho. The world of things. Ethno-Art: teaching aid. Yakutsk: Publishing house the company "Dani Almas", 2009. 